\title{
Risk perception - issues for flood management in Europe
}

\author{
R. A. Bradford ${ }^{1}$, J. J. O’Sullivan ${ }^{1}$, I. M. van der Craats ${ }^{2}$, J. Krywkow ${ }^{3}$, P. Rotko ${ }^{4}$, J. Aaltonen ${ }^{4}$, M. Bonaiuto ${ }^{5}$, \\ S. De Dominicis ${ }^{5}$, K. Waylen $^{6}$, and K. Schelfaut ${ }^{2,7}$ \\ ${ }^{1}$ Centre for Water Resources Research, University College Dublin, Belfield, Dublin 4, Ireland \\ ${ }^{2}$ Antea Group, Poortakkerstraat 41, 9051 Gent, Belgium \\ ${ }^{3}$ Seeconsult GmbH, Sedanstrasse 61, 49076 Osnabruck, Germany \\ ${ }^{4}$ Suomen Ymparistokeskus (Finnish Environment Institute), Helsinki, Finland \\ ${ }^{5}$ Centro Interuniversitario di Ricerca in Psicologia Ambientale and Dipartimento di Psicologia dei Processi di Sviluppo \\ e Socializzazione, Sapienza Università di Roma, Rome, Italy \\ ${ }^{6}$ James Hutton Institute, Aberdeen, Scotland, AB15 8QH, UK \\ ${ }^{7}$ University of Ghent, Vakgroep Geografie, Krijgslaan 281-S8, 9000 Gent, Belgium
}

Correspondence to: R. A. Bradford (roisin.bradford@ucd.ie)

Received: 13 January 2012 - Revised: 19 April 2012 - Accepted: 30 May 2012 - Published: 20 July 2012

\begin{abstract}
Public perception of flood risk and flood risk information is often overlooked when developing flood risk management plans. As scientists and the public at large perceive risk in very different ways, flood risk management strategies are known to have failed in the past due to this disconnect between authorities and the public. This paper uses a novel approach in exploring the role of public perception in developing flood risk communication strategies in Europe. Results are presented of extensive quantitative research of 1375 questionnaire responses from thirteen communities at risk across six European countries. The research forms part of two research projects funded under the 2nd ERA-Net CRUE Funding Initiative: URFlood and FREEMAN. Risk perception is conceptualised as a pillar of social resilience, representing an innovative approach to the issue. From this process recommendations are identified for improving flood risk management plans through public participation.
\end{abstract}

\section{Introduction}

Flooding accounts for approximately one third of all natural disasters in both the developed and developing worlds (UNISDR, 2012). Floods are also responsible for more than half of all disaster related fatalities and a third of the economic loss from all natural catastrophes (White, 2000). While the reporting of flood events has undoubtedly improved, evidence suggests that the frequency and severity of flood incidents has increased (EM-DAT, 2011). Climate change influences and increasing urbanisation of watersheds, amongst others, are contributing factors in this regard (Kay et al., 2011; Mc Carthy, 2001; Nirupama and Simonovic, 2007). It is now recognised that flood mitigation measures based solely on structural protection are unsustainable and will not eliminate inundations from extreme floods indefinitely (Kundzewicz, 1999; Tobin, 1995). This recognition has resulted in a paradigm shift in how responsible authorities across Europe deal with floods. A multi-facetted flood risk management approach that more heavily embraces nonstructural measures of improved land-use planning, relocation, flood proofing, flood forecasting and warning and insurance is now advocated. These approaches that are based on a continuous holistic and societal analysis together with an assessment and mitigation of flood risk (Mc Gahey et al., 2009) are now engrained in national policies across Europe (see, for example, Defra, 2005; Ruimte voor de Rivier, 2011) and are underpinned by the EU Floods Directive 2007/60/EC (European Parliament and the Council of the European Union, 2007).

Although the social aspects of floods have been reported for some time (Horton and Jackson, 1913; White, 1945, both cited in Marincioni, 2001), their understanding in the context of flood risk management has become increasingly important (Brown and Damery, 2002). Perception of risk at both an individual and public level represents a key societal component in flood risk management that is integral to determining the 
response to flood warnings and efforts to increase community preparedness. Previous flood risk management policies have been known to fail or be adversely affected when policy makers overlook the subjective and highly contextualised nature of public perception (Granger-Morgan, 1997; Brown and Damery, 2002). For example, a major issue during the UK 2007 summer floods was identified as the poor response of the public to Environment Agency warnings. Responses were found to differ according to whether people were aware of their own risk (Pitt, 2007). This lack of understanding by the agencies involved in the public's perception of risk rendered many warnings ineffective. In addition, public information campaigns such as the Dutch 2006 "Think Ahead" campaign are often found to have little impact despite many people receiving the information. Terpstra (2010) advocates that considering how the public perceive risk will improve such campaigns. Success of flood risk management policies, therefore, relies on understanding how the public construct risk concepts.

This research explores the role of public perception in flood risk management. Following from the concept of Raaijmakers et al. (2008) that relates flood risk perception to three indicators of awareness, preparedness and worry; the paper links self-assessed measures of these indicators from individuals in at-risk communities across Europe to direct experience of previous floods as well as the demographic profile of the individual in terms of gender, education level and employment status. The effect that risk perception has on how the public behave during a flood emergency in terms of evacuation is also discussed. The results presented are drawn from the URFlood and FREEMAN projects that were funded under the 2nd ERA-Net CRUE research initiative undertaken between September 2009 and August 2011 and are derived from case study research in six European countries. Thirteen case studies that comprised a questionnaire survey of 1375 individuals that are vulnerable to any or a combination of pluvial, fluvial and coastal flood risks were undertaken. Comparisons of responses from this sample are made to findings reported in literature that draw on experiences reported from other floods. Based on these, recommendations are made to improve the social dimension of flood risk management plans by identifying key issues pertaining to the role of public perception and awareness in flood risk management.

\section{Risk perception and flood risk management}

The way in which the public perceive risk is complex and is heavily influenced by situational and cognitive factors (Tobin and Montz, 1997). Situational factors reflect an individual's physical location in relation to a flood prone area and are, therefore, subject to characteristics of the hazard. Previous flood experience as well as socio-economic and demographic profiles (age, gender, education level, income) of those at risk is important in this regard. Cognitive factors on the other hand, reflect the personal and psychological composition of an individual and include affective and behavioural attributes that account respectively for particular emotions evoked by flooding and tendencies or dispositions to act in specific ways when flooded. The complexity of how risk is perceived by the public is at odds with how risk is defined in the scientific community. Risk according to the scientist is described by Eq. (1) (UNISDR, 2012; Kron, 2002);

Risk $=$ hazard $\times$ vulnerability $\times$ exposure

where the hazard is the threatening event (in this case a flood) including its probability of occurrence, vulnerability is the lack of resistance to damage and exposure is presence of people or infrastructure at the location involved (Kron, 2002). In this context, risk is measured statistically by flood risk managers. Most citizens, however, include experiences, emotions and feelings in their perception of risk, producing a measure that relies on intuitive risk judgements. Public conceptualisation of risk includes elements that are omitted or underestimated by scientific risk assessments, often resulting in reduced public confidence in the risk decision process (Slovic, 2000; Baan and Klijn, 2004). Understanding how the public perceive risk is, therefore, crucial in determining how appropriate flood related information should be disseminated to the public in a manner that will increase public trust in authorities, leading to enhanced capacity to respond to floods and increased resilience. Many definitions of resilience exist within the literature as resilience has many dimensions including social, physical, economic, institutional and ecological. This paper focuses on the aspect of social resilience which can be defined as the capacity of a community to adapt (by resisting or changing) in order to reach and maintain its survival and functioning; it incorporates the capacity to recover with minimal social disruptions (Samuels et al., 2005; UNISDR, 2005; Manyena, 2006).

In general terms, risk perception can be considered as an individual's interpretation or impression based on an understanding of a particular threat that may potentially cause loss of life or property. More formal definitions exist in literature. Wilson (1990) views perception in the context of transforming input (e.g., flood warning) to output (e.g., mitigation response). Risk perception is defined by Slovic (2000) as the intuitive judgement of individuals and groups, of risks in the context of limited and uncertain information. Raaijmakers et al. (2008) specifies this definition and defines perception through the relationship of a specific set of risk characteristics: awareness, worry and preparedness. Increasing any or a combination of these raises the perception of risk and in so doing can contribute to enhanced flood resilience. Over time, worry and, therefore, awareness will decrease (Fig. 1).

Awareness is, therefore, a vital element for a community to effectively adapt to a flood risk and according to Shen (2009) it is diminished when the provision of appropriate information is low or when memories of previous events diminish. 


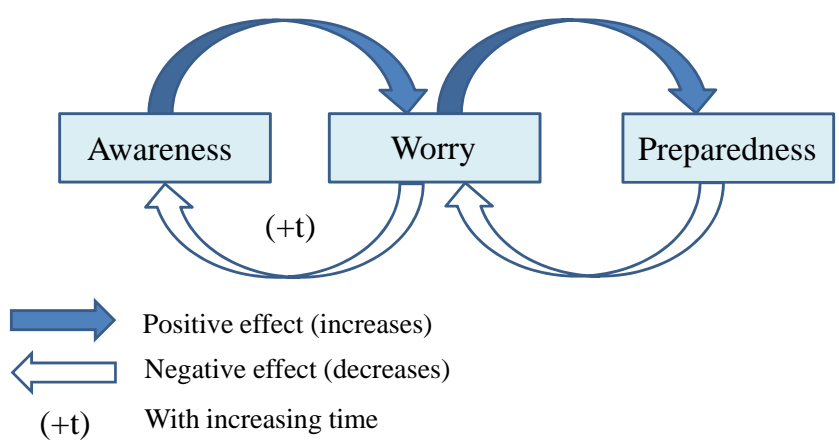

Fig. 1. Relationship between elements of risk perception (from Raaijmakers et al., 2008).

Although differences in how best to raise awareness are reported in the literature (Shidawara, 1999; Poortinga et al., 2011), it is generally recognised that levels can be raised through efforts that are focussed on local issues, contain simple solutions to reduce the risk and are repeated on a regular basis (Fischer, 1995; Haggett, 1998; Poortinga et al., 2011; Uggla, 2008). Worry in the context of Fig. 1 refers to the emotional reactions of individuals exposed to a risk (Sjöberg, 1998).

Worry is a necessary risk characteristic that serves as a normative value for awareness. An individual can be aware of a flood risk, however, if the individual is not afraid of this risk, he or she will not take any action to prepare. A higher level of worry is more likely to result in a higher level of preparedness (Raaijmakers et al., 2008; Miceli et al., 2008). Reliance on public structural flood protection can, however, serve to reduce worry and, therefore, community preparedness (Terpstra, 2011; Grothmann and Reusswig, 2006). Those who rely excessively on others without taking ownership of the flood risk and responsibility for protecting their own properties are also likely to be less prepared (Lindell and Whitney, 2000; Grothmann and Reusswig, 2006; Keogh et al., 2011). However, the relationship between awareness, worry and preparedness is not clear and conflicting results are often found in the literature (Siegrist and Gutscher, 2008). Figure 1 shows that worry plays a central role in the relationship between awareness and preparedness; individuals may be aware of a risk, but underestimate the consequence of that risk. This paper, therefore, asks the question "Is worry the link between awareness and preparedness?"

\section{Methodology}

Case study research was undertaken in Belgium, Finland, Germany, Ireland, Italy and Scotland forming part of the twoyear URFlood (Understanding Uncertainty and Risk in Communicating about Floods) and FREEMAN (Flood Resilience Enhancement and Management) 2nd call ERA-Net CRUE projects. The thirteen case studies (Fig. 2) encompassed a

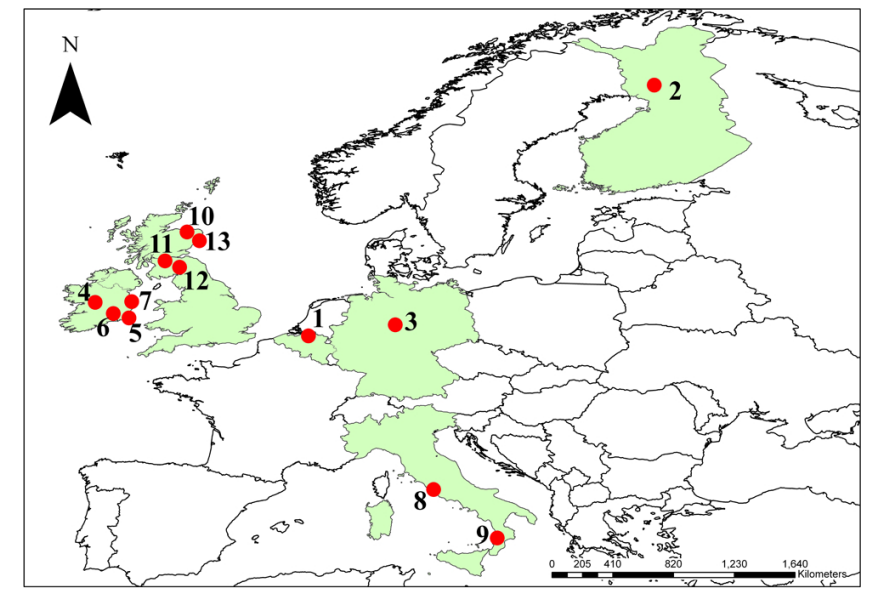

Fig. 2. Case study locations (numbers correspond with Table 1).

range of catchment sizes, flood history and flood risks including fluvial (river flooding), pluvial (rainfall generated flooding) and coastal (inundation of land by sea water) (Tables 1 and 2). Some case studies included areas where flood defences have been implemented, facilitating an assessment of residual risk on public perception. The research followed a people-centred approach, collecting quantitative data from the public at risk through self-completion questionnaires. Questionnaires were specifically tailored (in terms of type and number of questions asked) in each case study area to satisfy local needs. However, key topics such as awareness and preparedness levels, together with previous flood experiences were assessed using questionnaires that were developed using the key principles of questionnaire design. Questionnaires were, therefore, of a pre-coded and precise nature and refinement through piloting ensured simple unambiguous language that minimised risk of misunderstanding. Key questionnaire variables are shown in Table 3.

The sampling procedure adopted included a mixed method approach of postal, in-person and online surveys, producing a large sample size of 1375 questionnaire returns (Table 1). All case studies only targeted people that were at risk of flooding and included those with $(56 \%)$ and without (44\%) previous flood experience. Individuals living within probabilistic flood envelopes (the 100-yr and 200-yr envelopes for fluvial and coastal risks, respectively) and those residing within designated risk areas (including pluvial risk) were specifically targeted. The SPSS (originally Statistical Package for the Social Sciences) predictive analytics software package (SPSS, 2009) was employed to analyse the data using a set of independent variables including previous flood experience, previous evacuation behaviour, knowledge of evacuation routes, gender, level of education, employment status and age. Statistical significance levels were assessed through chi-square tests, independent samples t-tests, as well as one-way analysis of variance (Anova). The critical significance value (pvalue) was set at 0.05 following the usual convention that 
Table 1. Characteristics of case studies undertaken.

\begin{tabular}{lllll}
\hline Country & Case study site & $\begin{array}{l}\text { Size of } \\
\text { catchment }\end{array}$ & Type of risk & $\begin{array}{l}\text { No. completed } \\
\text { questionnaires }\end{array}$ \\
\hline Belgium & 1. Demer Basin & $1920 \mathrm{~km}^{2}$ & Fluvial, pluvial & 207 \\
\hline Finland & 2. Rovaniemi & $51127 \mathrm{~km}^{2}$ & Fluvial & 325 \\
\hline Germany & 3. Innerste Basin & $1264 \mathrm{~km}^{2}$ & Pluvial & 26 \\
\hline \multirow{5}{*}{ Ireland } & 4. Ballinasloe, Co. Galway & $1590 \mathrm{~km}^{2}$ & Fluvial & 84 \\
& 5. Wexford Town, Co. Wexford & $6.39 \mathrm{~km}^{2}$ & Coastal & 78 \\
& 6. Clonmel, Co. Tipperary & $2173 \mathrm{~km}^{2}$ & Fluvial, residual & 126 \\
& 7. River Dodder, Dublin & $125 \mathrm{~km}^{2}$ & Fluvial, pluvial, coastal, residual & 148 \\
\hline \multirow{2}{*}{ Italy } & 8. Rome & $445 \mathrm{~km}^{2}$ & Fluvial, pluvial & 134 \\
& 9. ViboValentia/Bivona & $46 \mathrm{~km}^{2}$ & Coastal, pluvial & 103 \\
\hline \multirow{2}{*}{ Scotland } & 10. Huntly & $1266 \mathrm{~km}^{2}$ & Fluvial & 50 \\
& 11. Glasgow/Whitecart & $250 \mathrm{~km}^{2}$ & Fluvial, residual & 37 \\
& 13. Newburgh & $960 \mathrm{~km}^{2}$ & Fluvial & 21 \\
\hline
\end{tabular}

if there is less than a $5 \%$ probability that an observed pattern occurred due only to chance variation in the data, it is accepted that the observed pattern is not due to chance. The results section only reports results that reached statistical significance.

\section{Results and discussion}

The sample profile as shown in Table 4 was compared with European census data (European Commission, 2011) to investigate whether the sample was representative of a larger population in terms of gender, age, attained education level and employment status. The research sample was found to have a slight over representation of males (54\% in sample compared with $49 \%$ in census), older respondents ( $22 \%$ of sample over the age of 65 compared with $17 \%$ in census) and higher education (45\% of the sample reached a third level of education or higher (using the ISCED (2011) definition of tertiary education), which is slightly higher than the census average of $32 \%$ for the partner countries). The high retirement rate $(24 \%)$ reflects the age bias, while the sample is under represented in terms of unemployment $(4.5 \% \mathrm{com}-$ pared with $8.5 \%$ in census). However, a wide range of age groups, education levels and employment statuses were represented, which when combined with the large sample size allowed the sample to be considered sufficiently robust for generalisation of findings. Results were initially analysed in terms of the Raaijmakers et al. (2008) concept of risk perception (Fig. 1) and, therefore, involved an exploration of risk awareness, preparedness and worry. In addition, and because of its importance in flood risk management strategies,

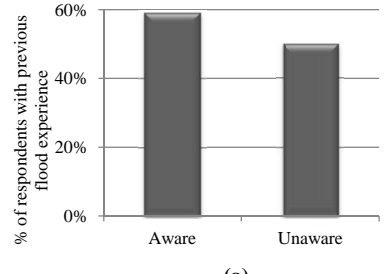

(a)

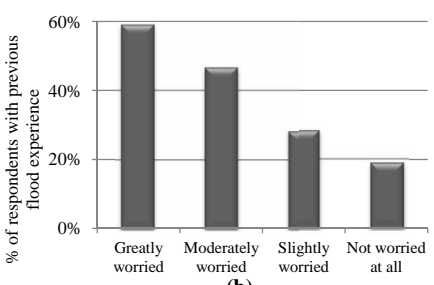

(b)

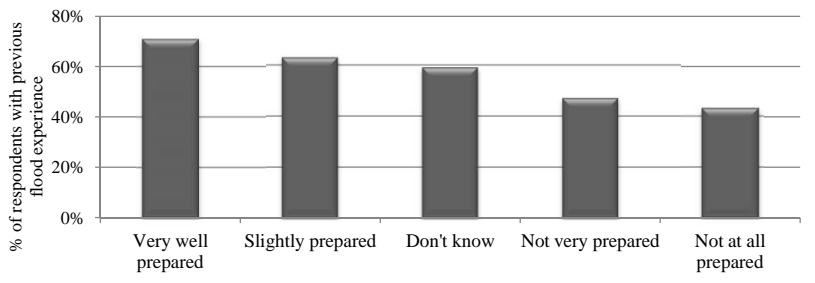

(c)
Fig. 3. Influence of previous flood experience on (a) awareness, (b) worry and (c) preparedness levels.

the role of these three indicators of perception in implementing evacuation orders for extreme events was investigated.

\subsection{Risk perception and awareness}

Prior to individuals and communities taking measures to improve their resilience to floods, they must be aware that they are indeed at risk of flooding. Awareness is, therefore, an integral component to effective flood risk management. Regardless of previous flood experience, all participants in this study were at risk. Awareness of this risk amongst respondents was generally good, with approximately $80 \%$ of 
Table 2. Characteristics of previous flood events by case study area.

\begin{tabular}{|c|c|c|c|c|c|c|c|c|}
\hline $\begin{array}{l}\text { Case } \\
\text { study } \\
\text { site }\end{array}$ & $\begin{array}{l}\text { Past flood events } \\
(1950-2010)\end{array}$ & Return period & Social impacts & $\begin{array}{l}\text { Economic } \\
\text { impacts }(€)\end{array}$ & Flood programme in place & $\begin{array}{l}\text { No. floods } \\
\text { in } \quad 0- \\
2 \text { yr } \\
(2008- \\
2010)\end{array}$ & $\begin{array}{l}\text { No. floods } \\
\text { in 2- } \\
10 \mathrm{yr} \\
(2000- \\
2008)\end{array}$ & $\begin{array}{l}\text { No. floods } \\
\text { in } 10- \\
50 \mathrm{yr} \\
(1950- \\
2000)\end{array}$ \\
\hline 1. & $\begin{array}{l}\text { Major events } \\
\text { Nov } 2010 \text {, } \\
\text { Dec } 2002 \text { and } \\
\text { Sep } 1998\end{array}$ & Not reported & $\begin{array}{l}690 \text { people affected, } 3 \text { casualties }(2010) \\
1200 \text { people affected, } 2 \text { casualties } \\
(2002) \\
140 \text { people affected (1998) }\end{array}$ & $\begin{array}{l}€ 180 \text { million } \\
(2010) \\
€ 16 \text { million } \\
(1998)\end{array}$ & $\begin{array}{l}\text { Dikes and retention areas. Flood fore- } \\
\text { casting and warning system. Flood } \\
\text { probability and damage maps. }\end{array}$ & 1 & 5 & 8 \\
\hline 2. & $\begin{array}{l}1993 \\
1981 \\
1973 \\
1967 \\
1966\end{array}$ & $\begin{array}{l}20 \mathrm{yr} \\
15 \mathrm{yr} \\
20 \mathrm{yr} \\
10 \mathrm{yr} \\
10 \mathrm{yr}\end{array}$ & Agriculture affected & Not reported & $\begin{array}{l}\text { Watershed Simulating and Forecasting } \\
\text { System. Flood action plan }\end{array}$ & 0 & 0 & 5 \\
\hline 3. & $\begin{array}{l}\text { Sep 2007, } \\
2003 \text {, } \\
1994, \\
1986 \\
1952\end{array}$ & $\begin{array}{l}100 \mathrm{yr} \text { event } \\
(2007) \\
100 \mathrm{yr} \text { event } \\
(1952)\end{array}$ & $\begin{array}{l}\text { 2007: Residential properties, infrastruc- } \\
\text { ture, transport networks, campsite af- } \\
\text { fected } \\
\text { Stress, psychological health effects, } \\
\text { loss of possessions, temporary evacu- } \\
\text { ation, disruption to daily life, reduced } \\
\text { quality of life, holiday disruption }\end{array}$ & Not reported & $\begin{array}{l}\text { Disaster management plan of Lower } \\
\text { Saxony (kurzfristig) } \\
\text { Flood management plan (langfristig) } \\
\text { Hazard and Risk Maps }\end{array}$ & 0 & 2 & 3 \\
\hline 4. & $\begin{array}{l}\text { Little until } \\
\text { Nov } 2009\end{array}$ & $200 \mathrm{yr}$ event & $\begin{array}{l}90+\text { properties affected. } \\
\text { Water supply affected }\end{array}$ & $€ 8.1$ million & No flood programme in place & 1 & 0 & 0 \\
\hline 5. & Oct 2004 & $65 \mathrm{yr}$ event & $\begin{array}{l}\text { Commercial and residential properties } \\
\text { affected. Electricity affected }\end{array}$ & Not reported & $\begin{array}{l}\text { Coastal Protection Strategy includes } \\
\text { flood maps }\end{array}$ & 0 & 1 & 1 \\
\hline 6. & $\begin{array}{l}2004,2000,1996 \\
\text { plus more minor } \\
\text { floods }\end{array}$ & $\begin{array}{l}5-25 \text { yr events } \\
50 \text { yr event } \\
(2004)\end{array}$ & $\begin{array}{l}260 \text { properties }(2000) \\
250 \text { properties }(1996)\end{array}$ & $\begin{array}{l}€ 859000 \\
(2000) \\
€ 774000 \\
(1996)\end{array}$ & $\begin{array}{l}\text { Flood Relief Scheme (2012) demount- } \\
\text { able barriers with } 100 \mathrm{yr} \text { protection }\end{array}$ & 1 & $\begin{array}{l}1 \text { major } \\
\text { several } \\
\text { minor }\end{array}$ & 18 \\
\hline 7. & $\begin{array}{l}\text { Severe tidal } \\
\text { floods Feb } 2002 \\
\text { Hurricane } \\
\text { Charlie } 1986\end{array}$ & $\begin{array}{l}100 \mathrm{yr} \text { event } \\
(2002) \\
>100 \mathrm{yr} \text { event } \\
(1986)\end{array}$ & $\begin{array}{l}120 \text { properties affected }(2002) \\
340 \text { properties affected (1986) }\end{array}$ & $\begin{array}{l}€ 7.6 \text { million } \\
(2002) \\
\text { Over } € 30 \text { mil- } \\
\text { lion }(1986)\end{array}$ & $\begin{array}{l}\text { CFRAM study includes flood maps, } \\
\text { structural defences. } \\
\text { Tidal flood warning system }\end{array}$ & 0 & 3 & 12 \\
\hline 8. & $\begin{array}{l}\text { Multiple floods } \\
\text { from the Tiber } \\
\text { (last 2008) }\end{array}$ & $\begin{array}{l}30 \mathrm{yr} \text { event } \\
(2008)\end{array}$ & $\begin{array}{l}\text { Damage to properties, roads, railways, } \\
\text { electricity, water }\end{array}$ & $€ 10$ million & $\begin{array}{l}\text { Plan of Tiber basin - Rome to river } \\
\text { mouth (2009) }\end{array}$ & 1 & 3 & 5 \\
\hline 9. & $\begin{array}{l}\text { July } 2006 \\
\text { pluvial flood. } \\
\text { Other floods } \\
\text { nearby }\end{array}$ & $\begin{array}{l}>100 \mathrm{yr} \text { event } \\
(2006)\end{array}$ & $\begin{array}{l}\text { Large-scale damage: buildings, infras- } \\
\text { tructure, transportation, } 600 \text { people af- } \\
\text { fected }\end{array}$ & $€ 155$ million & $\begin{array}{l}\text { Local development - Vibo Valentia } \\
\text { Emergency Programme (2007) }\end{array}$ & 0 & 2 & 4 \\
\hline 10. & $\begin{array}{l}\text { Nov } 2009 \text { "worst } \\
\text { in living } \\
\text { memory" }\end{array}$ & $25 \mathrm{yr}$ event & $\begin{array}{l}45 \text { properties, nursing home } \& \text { caravan } \\
\text { park }\end{array}$ & Not reported & $\begin{array}{l}\text { Future flood programme awaiting plan- } \\
\text { ning approval }\end{array}$ & 1 & 3 & 2 \\
\hline 11. & $\begin{array}{l}\text { More than } 20 \\
\text { significant floods } \\
\text { in } 50 \mathrm{yr}\end{array}$ & Not reported & $\begin{array}{l}\text { Residential and commercial properties, } \\
\text { transport links and agriculture affected }\end{array}$ & Not reported & $\begin{array}{l}\text { Recently completed flood programme } \\
\text { with } 200 \mathrm{yr} \text { protection }\end{array}$ & 0 & $\begin{array}{l}\text { Exact } \\
\text { figures } \\
\text { un- } \\
\text { known }\end{array}$ & $\begin{array}{l}\text { Exact } \\
\text { figures } \\
\text { un- } \\
\text { known }\end{array}$ \\
\hline 12. & $\begin{array}{l}2006 \\
2000\end{array}$ & $\begin{array}{l}1.2 \mathrm{yr} \text { event } \\
(2006)\end{array}$ & $\begin{array}{l}\text { Localised events. Some property dam- } \\
\text { age. }\end{array}$ & Not reported & Some structural defences present & 0 & 2 & 0 \\
\hline 13. & $\begin{array}{l}\text { None but } \\
\text { classified as } \\
\text { vulnerable by } \\
\text { SEPA }\end{array}$ & N/A & N/A & N/A & $\begin{array}{l}\text { No structural programme. SEPA Flood- } \\
\text { line system }\end{array}$ & 0 & 5 minor & 3 minor \\
\hline
\end{tabular}

respondents accepting they were at risk. Awareness was subsequently found to be strongly correlated to previous flood experience (chi-square $=6.7, d f=1, p=0.006$ ) (Fig. 3a). These results in themselves are not surprising and are consistent with the findings of others where previous experience is shown to be of importance in the learning process of dealing with floods (Pagneux et al., 2011; Burningham et al., 2008; Miceli et al., 2008; Weinstein, 1989). Flood events serve as reminders in a behavioural sense of appropriate actions that should be taken (Wilson, 1990) and frequent inundations ensure that the perception of risk and associated resilience levels remain high. Conversely, long periods without floods will serve to diminish awareness (Burn, 1999). This can be compounded for flood managers in urban areas where populations tend to be more mobile, with the result that knowledge of a localised flood risk may not readily be passed on between generations (Blyth et al., 2001); a problem that increases as the duration between floods becomes greater. The onus, therefore, is on flood managers to ensure that knowledge from experienced flood victims is captured and used as a resource in the development of flood risk management plans. Relating the hazard to possible consequences 
Table 3. Key variables investigated in questionnaires in Belgium (B), Finland (F), Germany (G), Ireland (IR), Italy (IT) and Scotland (S).

\begin{tabular}{|c|c|c|c|c|c|c|c|}
\hline Key topic & Key variables investigated & B & $\mathrm{F}$ & G & IR & IT & $\mathrm{S}$ \\
\hline \multirow[t]{2}{*}{ Awareness } & Perception of living in a flood risk area (Yes/No) & $\sqrt{ }$ & $\sqrt{ }$ & $\sqrt{ }$ & $\sqrt{ }$ & $\sqrt{ }$ & $\sqrt{ }$ \\
\hline & Awareness of evacuation routes (Yes/No) & $\sqrt{ }$ & - & $\sqrt{ }$ & - & - & - \\
\hline Worry & $\begin{array}{l}\text { Degree of worry regarding floods } \\
\text { (Likert scale: Not worried at all - greatly worried) }\end{array}$ & $\sqrt{ }$ & $\sqrt{ }$ & $\sqrt{ }$ & - & $\sqrt{ }$ & - \\
\hline Preparedness & $\begin{array}{l}\text { Self-assessed levels of personal preparedness } \\
\text { (Likert scale: Not prepared at all - very well prepared) }\end{array}$ & $\sqrt{ }$ & $\sqrt{ }$ & $\sqrt{ }$ & $\sqrt{ }$ & $\sqrt{ }$ & - \\
\hline \multirow[t]{2}{*}{ Experience } & Residence flooded previously (Yes/No) & $\sqrt{ }$ & $\sqrt{ }$ & $\sqrt{ }$ & $\sqrt{ }$ & $\sqrt{ }$ & $\sqrt{ }$ \\
\hline & Evacuation during previous floods (Yes/No) & $\sqrt{ }$ & - & - & $\sqrt{ }$ & - & $\sqrt{ }$ \\
\hline \multirow[t]{4}{*}{ Demographics } & Gender & $\sqrt{ }$ & $\sqrt{ }$ & $\sqrt{ }$ & $\sqrt{ }$ & $\sqrt{ }$ & $\sqrt{ }$ \\
\hline & Age & - & $\sqrt{ }$ & - & $\sqrt{ }$ & $\sqrt{ }$ & $\sqrt{ }$ \\
\hline & Education & $\sqrt{ }$ & - & $\sqrt{ }$ & $\sqrt{ }$ & $\sqrt{ }$ & $\sqrt{ }$ \\
\hline & Employment & $\sqrt{ }$ & - & $\sqrt{ }$ & $\sqrt{ }$ & $\sqrt{ }$ & $\sqrt{ }$ \\
\hline
\end{tabular}

Table 4. Gender, attained education levels, employment status and age of respondents.

\begin{tabular}{llrrrrrrr}
\hline Country & & Belgium & Finland & Germany & Ireland & Italy & Scotland & Average \\
\hline Gender & Male & $67.6 \%$ & $49.2 \%$ & $80.8 \%$ & $52.9 \%$ & $49.45 \%$ & $52.7 \%$ & $54.2 \%$ \\
& Female & $32.4 \%$ & $50.8 \%$ & $19.2 \%$ & $47.1 \%$ & $50.6 \%$ & $47.3 \%$ & $45.8 \%$ \\
\multirow{5}{*}{ Education } & 1st level & $3.4 \%$ & - & $0 \%$ & $10.2 \%$ & $28.4 \%$ & $30.9 \%$ & $15.3 \%$ \\
& 2nd level & $44.7 \%$ & - & $26.9 \%$ & $39.8 \%$ & $51.3 \%$ & $9.8 \%$ & $39.5 \%$ \\
& 3rd level + & $51.9 \%$ & - & $73.1 \%$ & $50 \%$ & $20.3 \%$ & $59.3 \%$ & $45.2 \%$ \\
Employment & Employed & $58.9 \%$ & - & $88.5 \%$ & $64.9 \%$ & $62.6 \%$ & $55.5 \%$ & $62.6 \%$ \\
& Unemployed & $2.9 \%$ & - & $3.8 \%$ & $6.3 \%$ & $3.9 \%$ & $2.4 \%$ & $4.5 \%$ \\
& Student & $0.5 \%$ & - & $0 \%$ & $2.2 \%$ & $9.5 \%$ & $0.8 \%$ & $3 \%$ \\
& Homemaker & $3.9 \%$ & - & $0 \%$ & $4.9 \%$ & $12.8 \%$ & $5.6 \%$ & $6.1 \%$ \\
\multirow{5}{*}{ Age } & Retired & $33.8 \%$ & - & $7.7 \%$ & $21.7 \%$ & $11.2 \%$ & $35.7 \%$ & $23.8 \%$ \\
& $<25$ & - & $4.0 \%$ & - & $1.2 \%$ & $13.1 \%$ & $0.8 \%$ & $4.8 \%$ \\
& $25-34$ & - & $5.9 \%$ & - & $13.5 \%$ & $19.8 \%$ & $3.9 \%$ & $10.8 \%$ \\
& $35-44$ & - & $15.8 \%$ & - & $18.5 \%$ & $25.3 \%$ & $26.6 \%$ & $21.6 \%$ \\
& $45-54$ & - & $25.2 \%$ & - & $21.3 \%$ & $19.8 \%$ & $19.5 \%$ & $21.5 \%$ \\
& $55-64$ & - & $18.9 \%$ & - & $20.1 \%$ & $15.6 \%$ & $23.4 \%$ & $19.5 \%$ \\
& $65+$ & - & $30.1 \%$ & - & $25.4 \%$ & $6.3 \%$ & $25.8 \%$ & $21.9 \%$ \\
\hline
\end{tabular}

can potentially generate greater concern amongst individuals to empower them to seek more information for use in the planning of effective mitigation strategies. This problem can also be addressed by the continued provision of information that highlights the existence of a risk and prescribes appropriate preventive and protective measures. Drawing attention to local flood management plans is, therefore, important in this regard.

From a flood risk management perspective, those that are at risk but don't consider themselves to be (approximately $20 \%$ of respondents in this study), are potentially of more concern. The lack of awareness of flood risk reported in this study could be explained, perhaps even justified, if those $(n=238)$ that were unaware had not been previously flooded. However, results indicate that a significant number of respondents $(n=118)$ were unaware of any risk despite having direct experience of previous floods. This issue was further investigated in the Irish case study areas where questionnaire returns were referenced to geo-spatial data. It was found that respondents who fell into this category resided in areas adjacent to structural flood protection works that had been constructed since the last reported flood. Results suggest, therefore, that residents in the vicinity of structural flood defences are instilled with a false sense of security and believe themselves to be immune from future flood risks. As one respondent quoted "With the flood defences now in operation, I could not imagine being flooded again". Similar results of low public risk awareness in structurally 
protected areas have been shown in the literature (Ludy and Kondolf, 2012; Terpstra, 2010; Lassa, 2011). However, it is unclear whether residents in these studies had been flooded previously. Further to this, it has been shown that government policy also overlooks residual risk, with lands behind structural defences not considered at-risk areas, often having only rudimentary flood warning systems (Ludy and Kondolf, 2012; Handmer, 2001). While in fact there is increased damage potential for those living behind structural flood defences (Enserink, 2004). Following from Fig. 1, it could be hypothesised that this reduced awareness in those living close to structural defences is due to decreased levels of worry resulting from the structural measures. However, an independent samples t-test showed this not to be the case ( $t=1.6, d f=752, p=0.102)$. Findings of the URFlood project highlighted low levels of understanding of the probabilistic terminologies that describe flood magnitudes and identified a disconnect between the language used by the engineering community and that understood by the public at large (Bradford et al., 2011). This failure to understand key terms is likely to be a contributing factor to the perceived immunity to risk of those protected by formal flood protection structures. As such structures are designed to provide a specified level of protection quantified in terms of recurrence intervals or return periods, public understanding of these terms will lead to recognition that these structures will be exceeded for events greater than the design capacity. A lack of awareness of and a 'switching off' to a prevailing residual risk will adversely affect the ability of residents to respond to a flood, should it arise. This presents additional challenges to flood managers in these areas that need to be overcome by continued education and communication of these remaining risks.

Other explanations for the poor awareness amongst those who were previously flooded may include a denial of risk, a reluctance to accept risk or a lack of concern regarding the risk. These factors can be attributed to unrealistic optimism, psychological attachment to the home or economic interests in not wishing to devalue the home by accepting and acknowledging risk (Burningham et al., 2008; Sjöberg, 2000; Poortinga et al., 2011; Rippetoe and Rogers, 1987). These factors represent barriers to community resilience and need to be specifically addressed in flood risk management communication plans. A role exists for the responsible agencies together with local and national media sources in this regard. Examples could include discussing risk in the media as well as at the local, regional and national level to normalise the concept of flood risk and help reduce risk denial. Publishing risk maps will identify at-risk areas and allow discussion to take place within the community, facilitating further acceptance of risk. Levels of risk awareness were shown to be unrelated to the demographic factors assessed in this study, indicating that efforts to raise awareness need to remain focussed on all social groupings. Furthermore, no obvious differences between those of different nationality or from different case studies were observed.

\subsection{Risk perception and preparedness}

High levels of preparedness will contribute to individual and community resilience and facilitate an improved response to a flood, thereby, reducing adverse consequences (Paton et al., 2006). Respondents in Belgium, Finland, Germany, Ireland and Italy $(n=1231)$ were requested to self-assess their preparedness levels, with just $34 \%$ of these respondents feeling prepared for future floods. While it may be expected that an awareness of residing in a flood risk area would promote higher levels of preparedness, an independent samples t-test found this not to be the case $(t=0.41$, $d f=1100, p=0.68)$. This suggests that increasing awareness on its own will not necessarily result in increased levels of preparedness. Although risk awareness had no direct influence on flood preparation, a significant relationship was found between previous flood experience and preparedness levels $(t=6.6, d f=1182, p<0.001)$ (Fig. 3c). This higher level of preparedness may in part be explained by the desire of individuals to avoid the often unanticipated negative emotions of insecurity, fear and helplessness experienced during a flood event (Terpstra, 2011). The positive impact of this experience may, however, be relatively short lived (Weinstein, 1989; Mulilis et al., 1990). In addition, it is common for individuals to assume that future flood events will be of the same magnitude as those previously experienced and may, therefore, only take mitigating actions that would have been appropriate for these prior events (Burn, 1999; Weinstein, 1989; Green et al., 1991; Howe, 2011). Furthermore, those that experience extreme events where mitigation measures taken were of little use can be overcome with a sense of helplessness that can lead some individuals to conclude that damage will result regardless of actions taken to protect property (Slovic, 2000). Findings from this study indicate, therefore, that a strong case exists for disseminating preparedness information specifically to those in vulnerable communities that have no direct experience of floods or those whose experience is based on events from some time in the past. The importance of being prepared and methods of improving preparedness levels needs also to be continuously highlighted in focussed flood risk communication strategies.

Gender differences in perceived preparedness levels were observed within the sample with males reporting higher levels than their female counterparts $(t=-4.9, d f=1154$, $p<0.001)$. However, the reasons for this are somewhat unclear and the finding may reflect higher confidence levels of males in their ability to take preventative actions, influenced by the role of the male in the family context (Miceli et al., 2008). As self-efficacy has a positive influence on preventive behaviour (Lindell and Whitney, 2000; Rippetoe and Rogers, 1987), results suggest that providing specific information on how preparedness measures can be implemented may increase confidence of women in their ability to protect their property. Stressing the importance of preparedness 
measures to all members of a household is, therefore, essential.

\subsection{Risk perception and worry}

Worry, fear or concern is reported as being either a direct or indirect motivator for promoting preventive behaviour amongst those at risk (Weinstein, 1989; Grothmann and Reusswig, 2006; Tanner et al., 1991). Self-assessed levels of worry were, therefore, investigated in the Belgian, Finnish, German and Italian case studies. The majority of respondents (65\% of 795) stated that they frequently worry about being flooded. This increased significantly for that fraction of the sample that had either direct experience of flooding (Fig. 3b) or were aware of their exposure to a flood risk $(t=7.9$, $d f=729, p<0.001$ and $t=7.2, d f=227, p<0.001$, respectively). Those with lower levels of education were also found to worry more about floods (1-way Anova, $F=5.9$, $p<0.003)$ supporting research by Sjöberg (1998). Given that a relationship exists between education and income levels (Hansen, 1970), it may be inferred that those in higher income brackets worry less about the consequences of floods. While this social grouping may experience greater financial loss than those less well off, better insurance cover together with the resources to more easily repair damaged properties and replace lost belongings ultimately reduces the impacts of floods.

Results contrast somewhat with other studies which found no relationship between worry and risk awareness or education (Pagneux et al., 2011; Poortinga et al., 2011). Moreover, women are often found to worry more about risks in the literature (Poortinga et al., 2011; Sjöberg, 1998), however, a strong relationship was not found between worry and gender in this study $(t=1.8, d f=750, p=0.07)$. Furthermore, no significant relationship was found between worry and preparedness levels within this study (1-way Anova, $F=1.4$, $p=0.234$ ) suggesting that worry on its own is not enough to motivate preventive behaviour for flood risks. Fear arousal is often advocated in order to increase risk perception (Kievik and Gutteling, 2010; Witte, 1992). For example, a 2005 campaign by the UK Green Party using an image of a catastrophically flooded and drowned Britain is described by O'Neill and Nicholson-Cole (2009) as a "fear appeal". As fear is measured by ratings of concern or worry (Rogers, 1975), this study shows that communications that evoke fear in vulnerable communities may not promote the desired response as results show that worry does not increase preparedness. This is reflected in climate change literature which reinforces the view that campaigns inducing fear are unlikely to promote engagement (O’Neill and Nicholson-Cole, 2009).

\subsection{Risk perception and evacuation plans}

Efficient evacuation plans are becoming increasingly important in flood risk management. Risk perception can have an important influence on whether individuals decide to evacuate during a flood emergency (Burnside et al., 2007; Smith and Tobin, 1979; Krasovskaia et al., 2001). Of the sample analysed in this study, $17 \%$ of 393 respondents who had experienced flooding in Belgium, Ireland and Scotland, evacuated their premises during the most recent floods. A further $64 \%$ of 233 respondents in Belgium and Germany expressed an awareness of evacuation routes. The influence of the indicators of risk perception (Fig. 1) in evacuation behaviour was assessed. Higher levels of risk awareness were shown to be correlated to those who chose to evacuate properties (chi-square $=5.05, d f=1, p=0.015$ ) but this awareness was not shown to translate to knowledge of evacuation routes. The findings support results from Sect. 4.2 that awareness alone is not sufficient to cause those at risk to take positive action. Furthermore, independent samples t-tests indicated that no significant relationship was found between levels of worry and previous evacuations. A relationship was, however, found between worry and knowledge of evacuation routes $(t=2.3, d f=209, p=0.023)$ suggesting perhaps that while worry may not lead directly to increased preparedness levels, it may lead to an increased understanding of the local impacts of floods. Those that evacuated properties in previous floods were shown to have higher preparedness levels ( $t=2.8, d f=364, p=0.006$ ) indicating that the upheaval and emotional stress expended during evacuations may instil a willingness amongst some to implement preparatory measures. The inclusion of personal accounts from flood victims in ongoing flood communications can serve to highlight adverse impacts of floods with a view to reinforcing the need to take mitigating measures. Knowledge of evacuation routes, associated with higher levels of worry, also led to respondents feeling more prepared for floods $(t=7.6$, $d f=181, p<0.001)$. This shows the need for locally tailored information that identifies safe routes and appropriate actions in times of flood.

\subsection{General discussion}

The findings of this study advance the understanding of how risk awareness, worry and preparedness contribute to the concept of risk perception. Figure 1 shows awareness contributing to worry and worry contributing to preparedness levels with the effect, that elevating any of the three indicators, raises perception and resilience. However, a similar framework (Fig. 4) for the current study shows no correlation between worry or awareness and preparedness levels. Worry is, therefore, found not to be the central characteristic in the link between awareness and preparedness. The findings do, however, reinforce the significance of direct flood experience in raising these three elements of perception. Findings show that while risk awareness is linked to concern of this risk, awareness and worry are not correlated to high levels of preparedness which would serve to enhance resilience. 


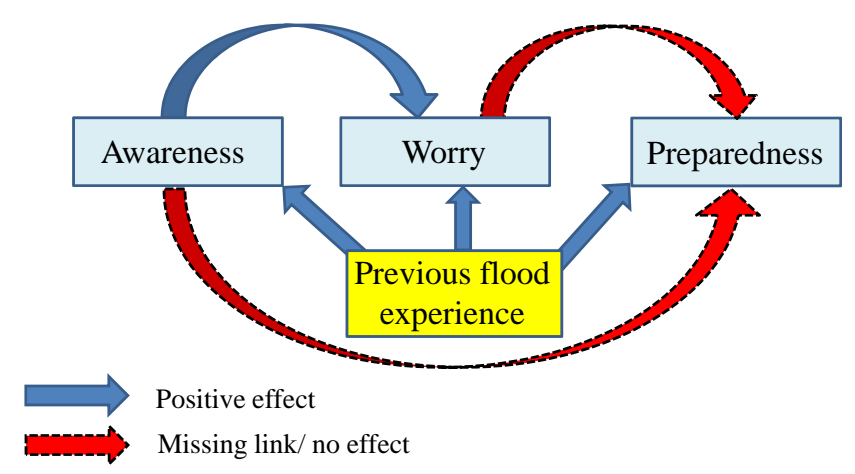

Fig. 4. Relationship between elements of risk perception in current study.

Given that significant numbers without direct flood experience continue to reside in areas exposed to flood risks, consideration from flood risk managers must be given to methods of how best to provide flood related information that serves to raise preparedness levels in the absence of the experiential learning developed when dealing with flood events. Based on the findings of the Irish and Scottish case studies in the URFlood project, the challenge is likely to be compounded in some communities where there is a belief that emergency responders and flood risk agencies are solely responsible for implementing preventative measures to protect properties and that self-protection is less important (Bradford et al., 2011).

\section{Conclusions}

Flood risk management plans have become increasingly important as a result of observed climate change impact and as a requirement of the EU Floods Directive 2007/60/EC. As these plans must take into account not only the physical nature of the risk but social factors, public risk perception must be at the core. Since the public view risk in a significantly different manner to the scientific community, those responsible for developing flood risk management plans need to understand the ways in which members of the public discern risk. Lack of understanding by authorities is known to cause failures in flood risk management policies. The study presented represents a novel approach towards incorporating public perceptions in the development of flood risk management plans. Based on an innovative approach of developing a social resilience model based on risk perception characteristics, recommendations were made on how to improve flood risk communication strategies. Risk perception can be characterised as a combination of awareness, worry and preparedness. Findings of this study, however, indicate that worry is not the central link between awareness and preparedness. Although fear arousal is often advocated in order to increase risk perception, these results show that communications that evoke fear in vulnerable communities may not promote the desired response.

Recommendations from this study can be summarised as follows:

1. as awareness is increased by previous flood experience, capturing knowledge from experienced flood victims can be used as a resource in flood risk communication;

2. providing understandable statements on risk will lead to recognition that structural protection measures will be exceeded for events greater than the design capacity, thus, reducing the issue of residual risk;

3. preparedness information needs to be tailored to those who are at risk, but have no direct experience of floods or whose experience is based on events from some time in the past;

4. including personal accounts from flood victims in ongoing communications can serve to highlight adverse impacts of floods, reinforcing the need to take alleviation measures;

5. locally tailored information that identifies safe routes and appropriate actions in times of flood should be provided;

6. providing specific information on easily implementable mitigation measures will increase confidence, especially in women, in personal ability to protect property;

7. as worry does not increase preparedness, communication strategies should not aim to evoke fear in vulnerable communities.

The practical findings in this study gathered through an innovative approach in utilising a social resilience model will facilitate flood managers in developing management plans that allow for the complexity in public perceptions of this risk. The paper will be useful in preparing risk communication strategies that will increase flood resilience in at-risk communities.

Acknowledgements. The authors would like to thank the ERA-Net CRUE research initiative in addition to the national funding organisations: Flanders Hydraulics Research; the Finnish Government; Bundesministerium für Bildung und Forschung (BMBF), through PTKA (Project Management Agency Research Centre Karlsruhe); the Irish Office of Public Works; Istituto Superiore per la Protezione e la Ricerca Ambientale (ISPRA); the Scottish Government and the Environment Agency. Special thanks to the representatives of the responsible organisations and administrations in each case study area.

Edited by: S. Mariani

Reviewed by: two anonymous referees 


\section{References}

Baan, P. J. A. and Klijn, F.: Flood risk perception and implications for flood risk management in the Netherlands, Int. J. River Basin Manage., 2, 113-122, 2004.

Blyth, K., Baltas, E., Benedini, M., and Givone, P.: Risk of inundation - planning and response interactive user system, Telematics Application Programme, 2001.

Bradford, R. A., O’Sullivan, J. J., Langan, S. J., Rotko, P., Bonaiuto, M., Twigger-Ross, C., Waylen, K., Aaltonen, J., Watson, R. D., and Carrus, G.: Improving flood communications in Europe: Results from vulnerable and impacted communities, Proceedings of the International Symposium on Urban Flood Risk Management, Graz, Austria, 553-558, 2011.

Brown, J. D. and Damery, S. L.: Managing flood risk in the UK: Towards an integration of social and technical perspectives, T. I. Brit. Geogr., 27, 412-426, 2002.

Burn, D. H.: Perceptions of flood risk: A case study of the Red River flood of 1997, Water Resour. Res., 35, 3451-3458, 1999.

Burningham, K., Fielding, J., and Thrush, D.: "It'll never happen to me": Understanding public awareness of local flood risk, Disasters, 32, 216-238, 2008.

Burnside, R., Miller, D. S., and Rivera, J. D.: The impact of information and risk perception on the hurricane evacuation decisionmaking of greater New Orleans residents, Sociol. Spectrum: Mid-South Sociological Association, 27, 727-740, 2007.

Defra: Making space for water: Taking forward a new government strategy for flood and coastal erosion risk management in England, available at: www.defra.gov.uk (last access: 1 December 2011), 2005.

EM-DAT: The OFDA/CRED International disaster database, available at: http://www.emdat.be/ (last access: 1 December 2011), Université Catholique de Louvain, Brussels, Belgium, 2011.

Enserink, B.: Thinking the unthinkable: The end of the Dutch river dike system? Exploring a new safety concept for the river management, J. Risk Res., 7, 745-757, 2004.

European Commission: Eurostat, available at: http://epp.eurostat. ec.europa.eu/ (last access: 1 December 2011), 2011.

European Parliament and the Council of the European Union: Directive 2007/60/EC of the European Parliament and of the Council of 23 October 2007 on the assessment and management of flood risks, 2007.

Fischer, R.: Control construct design in evaluating campaigns, Public Relat. Rev., 21, 45-58, 1995.

Granger-Morgan, M.: Public perception, understanding, and values, in: The industrial green game: Implications for environmental design and management, edited by: Richards, D. J., National Academy Press, Washington DC, 200-211, 1997.

Green, C. H., Tunstall, S. M., and Fordham, M. H.: The risks from flooding: Which risks and whose perception?, Disasters, 15, 227-236, 1991.

Grothmann, T. and Reusswig, F.: People at risk of flooding: Why some residents take precautionary action while others do not, Nat. Hazards, 38, 101-120, 2006.

Haggett, C.: An integrated approach to flood forecasting and warning in England and Wales, Water Environ. J., 12, 425-432, 1998.

Handmer, J.: Improving flood warnings in Europe: A research and policy agenda, Global Environ. Chang., 3, 19-28, 2001.

Hansen, W. L.: Income distribution effects of higher education, American Economic Rev., 60, 335-340, 1970.
Howe, P. D.: Hurricane preparedness as anticipatory adaptation: A case study of community businesses, Global Environ. Chang., 21, 711-720, 2011.

ISCED: International standard classification of education, UNESCO, available at: http://www.uis.unesco.org/Education/Pages/ international-standard-classification-of-education.aspx (last access: 1 December 2011), 2011.

Kay, A. L., Crooks, S. M., Pall, P., and Stone, D. A.: Attribution of autumn/winter 2000 flood risk in England to anthropogenic climate change: A catchment-based study, J. Hydrol., 406, 97112, 2011.

Keogh, D., Apan, A., Mushtaq, S., King, D., and Thomas, M.: Resilience, vulnerability and adaptive capacity of an inland rural town prone to flooding: A climate change adaptation case study of Charleville, Queensland, Australia, Nat. Hazards, 59, 699723, 2011.

Kievik, M. and Gutteling, J. M.: Yes, we can: Motivating Dutch citizens to engage in self-protective behaviors with regard to flood risks, University of Twente, the Netherlands, 2010.

Krasovskaia, I., Gottschalk, L., Saelthun, N. R., and Berg, H.: Perception of the risk of flooding: The case of the 1995 flood in Norway, Hydrol. Sci. J., 46, 855-868, 2001.

Kron, W.: Flood risk $=$ hazard $\times$ exposure $\times$ vulnerability, in: Flood defence, edited by: Wu, B., Wang, Z., Wang, G., Huang, G., Fang, H., and Huang, J., Science Press, New York, 2002.

Kundzewicz, Z. W.: Flood protection sustainability issues, Hydrol. Sci. J., 44, 559-571, 1999.

Lassa, J. A.: Japan's resilience to tsunamis and the lessons for Japan and the world: An early observation, in: Ash Center, Harvard Kennedy School, 2011.

Lindell, M. K. and Whitney, D. J.: Correlates of household seismic hazard adjustment adoption, in: Risk Analysis: An International Journal, Wiley-Blackwell, 13-26, 2000.

Ludy, J. and Kondolf, G.: Flood risk perception in lands "protected" by 100-year levees, Nat. Hazards, 61, 829-842, 2012.

Manyena, S. B.: The concept of resilience revisited, Disasters, 30, 434-450, 2006.

Marincioni, F.: A cross-cultural analysis of natural disaster response: The Northwest Italy floods of 1994 compared to the US Midwest floods of 1993, International Journal of Mass Emergencies and Disasters, 19, 209-236, 2001.

Mc Carthy, J. J.: Climate change 2001: Impacts, adaptation, and vulnerability: Contribution of working group II to the third assessment report of the intergovernmental panel on climate change, Cambridge University Press, 2001.

Mc Gahey, C., Sayers, P., Schanze, J., Walz, U., Petroschka, M., Luther, J., and Mens, M.: Methodology for a DSS to support long-term flood risk management planning, 2009.

Miceli, R., Sotgiu, I., and Settanni, M.: Disaster preparedness and perception of flood risk: A study in an Alpine valley in Italy, J. Environ. Psychol., 28, 164-173, 2008.

Mulilis, J.-P., Duval, T. S., and Lippa, R.: The effects of a large destructive local earthquake on earthquake preparedness as assessed by an earthquake preparedness scale, Nat. Hazards, 3, 357-371, 1990.

Nirupama, N. and Simonovic, S.: Increase of flood risk due to urbanisation: A Canadian example, Nat. Hazards, 40, 25-41, 2007.

O'Neill, S. and Nicholson-Cole, S.: "Fear won't do it" promoting positive engagement with climate change through visual and 
iconic representations, Sci. Commun., 30, 355-379, 2009.

Pagneux, E., Gísladóttir, G., and Jónsdóttir, S.: Public perception of flood hazard and flood risk in Iceland: A case study in a watershed prone to ice-jam floods, Nat. Hazards, 58, 269-287, 2011.

Paton, D., McClure, J., and Burgelt, P. T.: Natural hazard resilience: The role of individual and household preparedness, in: Disaster resilience: An integrated approach, Charles C Thomas, Springfield, Illinois, 2006.

Pitt, M.: The Pitt review: Learning lessons from the 2007 floods, An independent review, Cabinet Office, London, 2007.

Poortinga, W., Bronstering, K., and Lannon, S.: Awareness and perceptions of the risks of exposure to indoor radon: A populationbased approach to evaluate a radon awareness and testing campaign in England and Wales, Risk Anal., 31, 1800-1812, 2011.

Raaijmakers, R., Krywkow, J. R., and van der Veen, A.: Flood risk perceptions and spatial multi-criteria analysis: An exploratory research for hazard mitigation, Nat. Hazards, 46, 307-322, 2008.

Rippetoe, P. A. and Rogers, R. W.: Effects of components of protection-motivation theory on adaptive and maladaptive coping with a health threat, J. Pers. Soc. Psychol., 52, 596-604, 1987.

Rogers, R. W.: A protection motivation theory of fear appeals and attitude change, J. Psychol., 91, 93-114, 1975.

Ruimte voor de Rivier: Room for the river, Dutch Government, available at: http://www.ruimtevoorderivier.nl/ (last access: 1 December 2011), 2011.

Samuels, P., Gouldby, B., Klijn, F., Messner, F., van Os, A., Sayers, P., Schanze, J., and Udale-Clarke, H.: Language of risk, Project definitions. 2nd Edn., 2005.

Shen, X.: Flood risk perception and communication in different cultural contexts - a comparative case study between Wuhan, China and Cologne, Germany, Ph.D. Dissertation, University of Bonn, 2009.

Shidawara, M.: Flood hazard map distribution, Urban Water, 1, 125-129, 1999.

Siegrist, M. and Gutscher, H.: Natural hazards and motivation for mitigation behavior: People cannot predict the affect evoked by a severe flood, Risk Anal., 28, 771-778, 2008.
Sjöberg, L.: Worry and risk perception, Risk Anal., 18, 85-93, 1998. Sjöberg, L.: Factors in risk perception, Risk Anal., 20, 1-12, 2000.

Slovic, P.: The perception of risk, Earthscan Publications, London, 2000.

Smith, K. and Tobin, G. A.: Human adjustment to the flood hazard, Longman London and New York, 1979.

SPSS: PASW statistics 18.0, in: IBM, New York, 2009.

Tanner, J. F., Jr., Hunt, J. B., and Eppright, D. R.: The protection motivation model: A normative model of fear appeals, J. Marketing, 55, 36-45, 1991.

Terpstra, T.: Flood preparedness: Thoughts, feelings and intentions of the Dutch public, University of Twente, 2010.

Terpstra, T.: Emotions, trust, and perceived risk: Affective and cognitive routes to flood preparedness behavior, Risk Anal., 31, 1658-1675, 2011.

Tobin, G. A.: The levee love affair: A stormy relationship?, JAWRA J. Am. Water Resour. As., 31, 359-367, 1995.

Tobin, G. A. and Montz, B.: Natural hazards: Explanation and integration, The Guilford Press, New York, 1997.

Uggla, Y.: Strategies to create risk awareness and legitimacy: The Swedish climate campaign, J. Risk Res., 11, 719-734, 2008.

UNISDR: United Nations international strategy for disaster risk reduction, Hyogo Framework for 2005-2015: Building the Resilience of Nations and Communities to Disasters, 2005.

UNISDR: United Nations international strategy for disaster reduction, available at: http://www.unisdr.org (last access: 31 March 2012), 2012.

Weinstein, N. D.: Effects of personal experience on self-protective behavior, Psychol. Bull., 105, 31-50, 1989.

White, W. R.: Water in rivers: Flooding, A contribution to the world water vision, IAHR, UK, 2000.

Wilson, C.: Education and risk, in: Hazards and the communication of risk, edited by: Handmer, J. and Penning-Rowsell, E., Gower, England, 1990.

Witte, K.: Putting the fear back into fear appeals: The extended parallel process model, Commun. Monogr., 59, 329-349, 1992. 